\title{
AZ EURÓPAI UNIÓ PÉNZÜGYI RENDSZERÉNEK ÉPÍTMÉNYE
}

\author{
Müller János
}

A legutóbbi pénzügyi válság kitörését követő időszakban az Európai Unióban a bankszektor biztonságos müködését erősítő egész szabályozási arzenál és intézményi architektúra alakult ki. Jelentősen előrehaladt a Gazdasági és Monetáris Unió, a bankunió és a tőkepiaci unió építkezése. Árnyaltabb, egységesebb és a bankrendszer biztonságosabb működését segítő szabályozó rendszer alakult ki. Többszörös mérföldkőhöz érkeztünk. A globális pénzügyi válság óta eltelt egy évtized, az Európai Unió gyökerei hatvan éve erősödnek, negyedszázados az Európai Unió, húszéves az euró és az eurózóna, végül két olyan uniós ciklus zárult 2019-ben, amelynek építkezése, tanulságai kijelölhetik a jövő Európájának sorsát.

JEL-kódok: $\mathrm{F}_{3}, \mathrm{G}_{2}$

Kulcsszavak: uniós pénzügyi intézményrendszer, Európai Monetáris Unió, tőkepiaci unió, bankunió, bankhatóság, szanálás, stabilitási mechanizmus, monetáris alap, tőkekövetelmény, bankfelügyelet, felügyeleti hatóságok, egységes szabálykönyv, fintech, fiskális unió.

\section{BEVEZETÉS}

Az elmúlt időszakokban voltak olyan események, amelyek próbára tették az Európai Unió életképességét; ugyanakkor napjainkig ez volt az egyik leghosszabb válságmentes, a nyugodt gazdasági fejlődést, építkezést lehetővé tevő korszak is. E periódus elemzői felvonultatják az EU ragyogó jövőképétől a vizionált szétesés minden változatát, de kevesebb szó esik az átgondolt, többségében kiérlelt, szakmai építkezésről. Írásunk középpontjában az európai és így a magyar bankrendszer müködésének kialakult, várható intézményi és szabályozói környezete áll.

Az áttekintés érdekében bemutatjuk, hogy az EU erős alapjain, a különböző kihívások tanulságait figyelembe véve, hogyan alakult az EU pénzügyi és szabályozó rendszerének architektúrája. Ezt az áttekintést történelmi perspektívába kell helyezni, csak ilyen módon lehet megítélni, hogy mennyire erős vagy hiányos az ed-

1 Müller János vezető tanácsadó, Magyar Bankszövetség. E-mail: mullerjı@t-online.hu. 
dig megvalósult építmény. Bőven van még tennivaló, az épület egyes részeit át kell alakítani, de maga az építmény robusztus és erős. Az unió vezetői, döntéshozói tisztában vannak az előrelépés szükséges irányaival. Ezek megtétele több esetben sürgető, de az eredmény a politikai, hatalmi érdekek, a globális és unión belüli gazdasági kényszerek döntéseket befolyásoló, kényes egyensúlyának az elérésétől függ. Ezen nehéz kérdések: helytállás a globális versenyben, a gyorsuló digitális világban, szembenézni egy bármilyen kimenetelű brexit utáni helyzettel, kezelni a kétsebességes unió és az Európa-szkeptikusok fejlődést lassító problémáját.

Az EU pénzügyi intézményi és szabályozó rendszerének egy évtizedes fejlődését követjük nyomon, majd felvázoljuk a 2019-es ciklusváltó év kapcsán kialakult jövőképet, továbbá, hogy a továbblépés fontos feltételei közül mi és miért nem valósult meg.

\subsection{A pénzügyi rendszer építményének alapjai és az első ciklus (2009-2014)}

A 2010-es évek második fele jelentős változásokat és jövőbe mutató fejlődést hozott az Európai Unió történetében. Különösen igaz ez 2019-re, amely mérföldkő és ciklusváltó év. Ebben az időszakban lehetett múlt időben mondani, hogy a 2008-as globális pénzügyi válság, a recesszió és adósságválság legtöbb közvetlen, a bankszektort is érintő, negatív hatását sikerült leküzdeni. Ennek meg kellett fizetni az árát: szükségszerüen bekövetkezett egy banki túlszabályozás. Ugyanakkor le lehetett és le kellett vonni a válság tanulságait. Egyértelmü volt, hogy a válság kitörésekor sem a szabályozás, sem a felügyelet és a válságkezelés nem volt elég hatékony, intézményi és rendszerszintű válaszokat kellett keresni. Elindult egy folyamat, amelynek a hátterében a válság utáni Európa helyzetének mélyreható elemzése, a fenntartható, versenyképes növekedést finanszírozni képes bankrendszer működési feltételeinek szándéka állt. Az unió vezetői egyetértettek abban, hogy ki kell alakítani egy olyan rendszert, amely egy következő válság kialakulását képes időben jelezni, bekövetkezte esetén hatásait erősen visszaszorítani. „A jelen csak akkor nem ismétli meg a múltat, ha legyözésére jelentős erők gyülekeznek" - írta egy magyar szerző. ${ }^{2}$ Az évtized közepén úgy tünt, hogy az ezt az akaratot felmutató, jelentős erők léptek fel az unióban.

Elkezdődött a szabályozói struktúra, valamint az annak kialakítását és müködését lehetővé tevő intézményi rendszer építményének a kialakítása. Ennek az architektúrának az alapjai nem csupán a pénzügyi válság hatásaira adott válaszokban keresendők. 2008-2009-re az EU már elért egy olyan fejlödési szintet, amikor annak szerves részeként dönteni kellett a szervezeti, intézményi reformokról.

2 Ungvári Tamás (2015): Csalódások kora. Budapest, Scolar Kiadó, 519. o. 
Melyek tehát azok az alapok, amelyekre a 2009-ben kezdődő, két új uniós ciklus kezdetekor építeni lehetett, amelyek lehetővé tették létfontosságú kérdések vizsgálatát és azokra a válaszok keresését?

2017-ben ünnepelhettük a római szerződés aláírásának 6o. évfordulóját, aminek az alapján létrejött az Európai Gazdasági Közösség az NSZK, Franciaország, Olaszország és a Benelux-államok részvételével. Donald Tusk, az Európai Tanács elnöke az évfordulót így méltatta:

„Hatvan évvel ezelött hat ország államférfiai úgy döntöttek, hogy az igazi szabadság az együttes cselekvés szabadsága. Európa rémült és sebezhetö országai adták e vezetőknek az alázatot, a tisztánlátást és a bölcsességet, hogy aláírják a római szerzödést. Ezzel pedig olyan folyamatot inditottak el, amelynek révén azóta keleten és nyugaton is sok más ország lépett újra a szabadság és a jólét útjára. Ez a folyamat segített megértenünk azt, hogy ha Európa gyenge, akkor az európai országok önmagukban is gyengék. Ha azonban Európa erös, akkor a tagállamai is erösek. Csak egységben valósíthatjuk meg szuverenitásunkat, lehetünk valóban szabadok a szélesebb nagyvilágban. Ez igaz volt akkor, és ma is igaz. És még hatvan év múlva is igaz lesz."

A következő szakaszhatár 2018, a maastrichti szerződés (Szerződés az Európai Unióról), hatálybalépésének negyedszázados évfordulója; ez a szerződés tette lehetővé az Európai Unió megalakulását. Az Európai Uniónak három pillére volt: az Európai Közösségen belül az Európai Gazdasági Közösség, az Európai Szén- és Acélközösség, valamint az Európai Atomenergia Közösség (Euratom). Emellett a maastrichti szerződés tartalmazta az euró bevezetésének a követelményét is. Jelen írás célját is visszatükrözik az Európai Bizottság elnökének az évforduló kapcsán kifejtett gondolatai:

„...az Európai Uniót, az európai projektet nem tudjuk úgy elmagyarázni, hogy egyszerüen visszatekintünk a történelemben. Ez fontos, de ha fiatalabb embereket meg akarunk gyözni arról, hogy az Európai Unió ma és az elkövetkezö években nélkülözhetetlen, akkor az európai történelmet perspektívába, távlatokba kell helyezni. Mi Európa ma, mi lesz Európa holnap és holnapután?"4

Jeles évfordulót hozott a 2019-es év is: húszéves lett az unió közös valutája, az 1999. január 1-jén bevezetett euró. A Gazdasági és Monetáris Unió megvalósítását már a maastrichti szerződés is kitűzte, de az európai valutához vezető út több mint 20 évig tartott. Az Európai Bizottság 1969-es első feljegyzésétől ebben a témában és

3 Donald Tusk (2017): Beszéd az Európai Unió Parlamenti Elnökeinek Konferenciáján. Róma, március 17.

4 Jean-Claude Juncker (2016): Speech by European Commission at the 25th Anniversary of the Maastricht Treaty: „EU and Me”. Maastricht, 9 December. 
az 1970-es Werner-jelentéstől a maastrichti szerződés 1992-es aláírásáig közel 30 év telt el, amíg az eurót útjára indították. Az euró működésének első két évtizede alatt a világ második legfontosabb valutájává vált, és megerősítette stabilitását, szerepét.

A mai Európai Unió fenti mérföldköveiről, a hatvanadik, huszonötödik és huszadik évfordulóról azért emlékeztünk meg, hogy érzékelhető legyen, milyen stabilak az unió alapjai, és erre építve tekintsük át, milyen is volt az unió „tájképe” a 2014-ben induló ciklus idején.

Ebben a ciklusban az EU müködésének több évtizedes tapasztalata, a 2008-ban kirobbant nemzetközi pénzügyi és gazdasági válság hatásai, a globális piaci viszonyok változásai, a geopolitikai válságok kialakulása szükségessé tették, kikényszerítették az EU müködési feltételeinek újragondolását és olyan, már jóval korábban tervezett intézkedések, intézményi reformok bevezetését, amelyeket az előbb említett körülmények szükségszerüvé tettek.

Ebben a helyzetben az unió vezetőinek, a páneurópai eszmét valló tagországok vezetőinek lehetősége nyílt a kialakult helyzet értékelésére, a politikai teendők, prioritások meghatározására. Két alapvető következtetést fogalmaztak meg: először is meg kell erősíteni az unió értékalapú müködését, az uniós értékeket jobban be kell tartani, ennek keretében pedig az uniós döntéseket közelebb kell vinni az uniós polgárokhoz, a választókhoz. Másodszor, a gazdasági növekedés és munkahelyteremtés, az uniós versenyképesség javításának feladatát abszolút politikai prioritásként kell meghatározni. A helyzetértékelés és a politikai prioritások meghatározása vezetett annak az elvnek az elfogadásához és deklarálásához, hogy az unió kétsebességes szervezet; vannak a magországok és az úgynevezett periféria. A magországok megerősítése politikai elfogadást és prioritást nyert.

Mindezek alapján egyértelmű volt a feladat: meg kell erősíteni az unió intézményi rendszerét, felül kell vizsgálni és hatékonyabbá kell tenni a szabályozási mechanizmust. Ebben a keretrendszerben került sor az európai parlamenti választásokra 2014-ben, amelynek eredményeképpen megújult az Európai Bizottság, az Európai Tanács és a Parlament is.

A mögöttünk lévő, 2014-2019 közötti uniós ciklus elejére - a pénzügyi válság hatásait is felmérve - az európai vezetők közös akarata egybehangzott abban, hogy előre kell lépni. Az új irányok kijelölésének, a jövő útjának számos elemét lehetne bemutatni, de elemzésünk szempontjából két dokumentumot, jövőbe mutató tervet, iránymutatást ki kell emelnünk.

Az első az úgynevezett Juncker-terv. Az Európai Bizottság új elnöke, Jean-Claude Juncker az európai parlamenti választások után, 2014. július 15-én mutatta be politikai programját. „Önök az első Parlament, amely bizottsági elnököt választ” - mondta programjának ismertetésekor. Reformprogramot hirdetett, amelynek 
célja a szociális piacgazdaság erősítése, ideértve egy 300 milliárd eurós beruházási csomagot azzal a céllal, hogy erősítse a növekedést, a munkahelyteremtést és a versenyképességet.

Tíz területet jelölt meg, ahol az EU-nak konkrét eredményeket kell elérnie mandátumának öt éve alatt. Ezekből emeljük ki az elemzésünk szempontjából fontosabbakat: munkahelyek teremtése; a gazdaság és a beruházások újbóli gyorsabb növekedése; integráltabb és igazságosabb belső piac, megerősített ipari bázissal; szorosabb és igazságosabb Gazdasági és Monetáris Unió (EMU). Ez utóbbihoz kapcsolódóan volt egy fontos kitétele: haladjon tovább az Európai Monetáris Unió (EMU) reformja az egységes pénznem megőrzése érdekében, biztositva a gazdasági, fiskális és munkaerőpiaci konvergenciát az eurózóna tagországai számára. Ez a megfogalmazás politikai síkon már a kétsebességes unió kilátásba helyezését jelentette. A tervnek volt még egy olyan pontja, amelyet a jelenlegi helyzet, illetve a jövő szempontjából kell megemlíteni: az észszerü és kiegyensúlyozott szabadkereskedelmi megállapodást az Egyesült Államokkal, amely nem veszélyeztetheti Európa biztonságát, egészségügyi, élelmiszerbiztonsági, szociális és adatvédelmi rendszereit, ugyanakkor a transzatlanti piacok valós integrációja elemi érdeke lett volna az EU-nak. Mint ismeretes, ezt a megállapodást az amerikai elnökváltást követően nem írták alá, jóllehet - ismerve a jelenlegi geopolitikai feszültségek és a kereskedelmi háború negatív hatásait - fontos lett volna nemcsak Európa, hanem az USA számára is.

A következő, irányt mutató anyag az „öt elnök jelentése” néven ismert, cselekvési ütemtervet is tartalmazó dokumentum, amelyet 2015. június 22-én tettek közzé, és még abban az évben, július 1-jén lépett életbe. 5

E jelentés kidolgozásának fontos előzménye volt a 2014. októberi euróövezeti csúcstalálkozó, ahol egyetértés született abban, hogy „a gazdasági és monetáris unió zökkenőmentes müködéséhez létfontosságú a gazdaságpolitikák szorosabb koordinációja”. A csúcstalálkozó „az erőteljesebb gazdaságpolitikai koordinációt, a konvergenciát és a szolidaritást szolgáló konkrét mechanizmusok kidolgozása céljából” végzett munka folytatására, valamint „az euróövezet jobb gazdasági irányítását segítő intézkedések” kidolgozására szólított fel.

Az öt elnök javaslatának lényege, hogy 2015 és 2025 között három szakaszban meg kell valósítani a Gazdasági és Monetáris Uniót (GMU), azzal a kikötéssel, hogy a szabályok helyett az intézményeket kell a középpontba helyezni annak érdekében, hogy a GMU-nak szilárd és átlátható szerkezete legyen. Jean-Claude Juncker

5 Az öt elnök az Európai Bizottság elnöke, Jean-Claude Juncker, valamint az euróövezeti csúcstalálkozó elnöke, Donald Tusk, az eurócsoport elnöke, Jeroen Dijsselbloem, az Európai Központi Bank elnöke, Mario Draghi és az Európai Parlament elnöke, Martin Schulz. 
elnök a bejelentéskor így fogalmazott: „Az euró 19 uniós tagállam és több mint 330 millió uniós polgár közös pénze - büszkék lehetünk rá. Védelmet nyújt Európának, ugyanakkor sokkal többre is képes lenne. Gazdasági és Monetáris Uniónk továbbra sem teljes. A mai napon négy elnöktársammal együtt elöterjesztjük közös jövőképünket. A világ figyel bennünket, és tudni akarja, merre tartunk. A mai napon lefektetjük a monetáris integráció végső célhoz vezetö ütemtervét."

A jelentés három különálló szakaszt határozott meg az öt elnök jövőképének megvalósításához:

- 1. szakasz, az elmélyítés szakasza (2015. július 1-jétől 2017. június 30-ig): a versenyképesség és a strukturális konvergencia fokozása, felelős nemzeti és euróövezeti szintű költségvetési politikák elérése, a pénzügyi unió megvalósítása.

- 2. szakasz, a Gazdasági és Monetáris Unió megvalósítása: több intézkedést vezetnek be annak érdekében, hogy a konvergenciafolyamat mindinkább kötelezővé váljon jogi jelleget öltő, közösen megállapított, irányadó konvergenciamutatók, valamint az euróövezeti kincstár révén.

- 3., végső szakasz (legkésőbb 2025-ig): az összes lépés teljes mértékű megvalósítása után a valódi GMU stabil és pozitív életteret biztosít a közös fizetőeszközt használó uniós tagállamok valamennyi polgárának, és vonzóvá válik a többi uniós tagállam számára, ha készen állnak a csatlakozásra.

A jelentés megállapította, hogy szükséges a gazdaságpolitika szorosabb koordinációja annak érdekében, hogy a közös valuta és az euróövezet által kínált lehetőségek teljes mértékben kihasználhatók legyenek. Az együttműködés négy területének adtak prioritást: a gazdasági unió; pénzügyi unió; fiskális unió és a politikai unió megvalósítása.

Az első szakasz fontos feladatként tűzte ki az európai szemeszter felülvizsgálatát (a 2010-ben elindított európai szemeszter a költségvetési és gazdaságpolitikák uniós koordinálására szolgáló ciklus, része az Európai Unió gazdaságirányítási keretrendszerének.) A felülvizsgálat részeként kellett felállítani a nemzeti versenyképességi igazgatóságokat, valamint az Európai Fiskális Igazgatóságot.

Az öt elnök jelentése mélyrehatóan foglalkozott a konvergencia folyamatának erősítésével, a versenyképesség javításával vagy a demokratikus elszámoltathatóság kérdésével. A bankszektor szempontjából különösen fontos a pénzügyi unió és a költségvetési unió felé teendő lépésekre vonatkozó javaslatuk. Az előbbivel kapcsolatban leszögezték, hogy a gazdasági és pénzügyi unió biztonságos müködéséhez egységes bankfelügyeletre, egységes bankszanálásra és egységes betétbiztosításra van szükség. Az egységes felügyeleti mechanizmusra vonatkozó célt már sikerült megvalósítani. Az egységes szanálási mechanizmusról és a kapcsolódó 
Egységes Szanálási Alapról (amely 2016. január 1-jével lépett müködésbe) már akkor megállapodás született. Következő lépésként a jelentés szerint szükséges lesz az európai betétbiztosítási rendszer létrehozása.

A költségvetési unió megalapozása érdekében létrehozták az Európai Költségvetési Tanácsot, amelynek közös makrogazdasági stabilizációs funkciót kell betöltenie, továbbá döntöttek az Európai Stratégiai Beruházási Alap felállításáról.

A fenti folyamatok egyértelművé tették, hogy javítani kell a szabályozási környezetet, amit megerősített az Európai Tanács 2015. májusi döntése. A Tanács megállapította, hogy a jobb szabályozás kulcsfontosságú a gazdasági növekedés és az innováció serkentésében, a versenyképesség és az egységes piac erősítésében. Ennek érdekében biztosítani kell az EU-szabályozás átláthatóságát, egyszerűségét, továbbá, hogy a legkisebb költséggel legyen alkalmazható. Ennek jegyében fogadták el a „Jobb szabályozás: jobb eredmények” (Better regulation for better results) címü programot.

\subsection{Az építkezés folytatódik: új ciklus, új kihívások (2014-2019)}

2015-ben az előbb vázolt fejlemények hatására előtérbe kerültek a tőkepiaci unió megvalósításának feltételei, aminek az alapvetése az volt, hogy a lehető legteljesebb egyensúly alakuljon ki a válság kezelése és a növekedés támogatása között.

Az Európai Bizottság 2015. szeptember 30-án mutatta be az Egységes Tőkepiaci Unió Akciótervet azzal a céllal, hogy mind a 28 tagállamra kiterjedően létrehozza a valódi egységes tőkepiacot. ${ }^{6}$

A tőkepiaci unió fontos pillére a beruházási tervnek, feladata a beruházások kívánatosnál alacsonyabb szintjét emelni, aminek az első lépése az üzleti célok meghatározása, valamint a hosszú lejáratú projektek finanszírozási forrásainak növelése és diverzifikálása.

A tőkepiaci unió négy alapelve:

1) Több és nagyobb lehetőség biztosítása a befektetők számára.

2) A finanszírozás összekapcsolása a reálgazdasággal.

3) Egy ellenállóbb és erősebb pénzügyi rendszer megteremtése.

4) A pénzügyi integráció erősítése és a verseny növelése.

Az időben előrelépve meg kell említeni, hogy az Európai Tanács már 2017 júliusában döntést hozott a tőkepiaci unióról szóló akcióterv bizottsági felülvizsgála-

6 EC (2015): Capital Market Union: An Action Plan to boost business funding and investment financing. ECFIN E-news, Iss. 124, 1 October. 
táról. A Tanács megerősítette elkötelezettségét a cselekvési terv iránt, amelynek a célja a teljes körű tőkepiaci unió létrehozása 2019 végéig: „Az európai gazdaság a folyamatos javulás jeleit mutatja, jelenleg azonban leginkább a beruházások növelésére van szükség. A tőkepiaci unió ezért szerepel kiemelt helyen a Bizottság által elfogadott programban. A fenntartható gazdasági növekedés hosszabb távon történő biztositása érdekében alapvető fontosságú az elérhetö finanszírozási források körének szélesitése, különösen az induló és innovatív vállalkozások számára."

Az európai bankrendszer működési környezete szempontjából jelentős lépés volt 2016 júniusa, amikor az Európai Bizottság elfogadta az EU és az EEA (Európai Gazdasági Térség) Egyesített Bizottságának javaslatát, amelyet az Európai Tanács elé terjesztett, hogy az európai felügyeleti hatóságok szabályai és egy sor kapcsolódó szabály és direktíva legyen átvéve az EEA jogrendjébe.

Ezáltal erősödött az EU gazdasági ereje és versenyképessége. Ezek a törvények az alábbiak: az európai felügyeleti hatóságok szabályai (EBA, EIOPA és ESMA); az Európai Rendszerkockázati Tanács szabályai (European Systemic Risk Board Regulation); az alternatív befektetési alap kezelésének direktívája (Alternative Investment Fund Managers Directive); a rövidre eladás szabályozása (Short Selling Regulation); az európai piaci infrastruktúra szabályozása (European Markets Infrastructure Regulation - EMIR); a hitelminősítő ügynökség szabályozása (Credit Rating Agency Regulation).

Ezeknek a törvényeknek és szabályoknak az átvétele erős és koordinált pénzügyi felügyeletet eredményezhetett az egész Európai Gazdasági Térségben.

Újabb mérföldkőnek tekinthető az Európai Tanács Állandó Képviselőinek Bizottságában (Coreper) létrehozott megállapodás, amelyet a pénzpiaci alapok (Money Market Funds - MMF) reformját illetően hoztak létre 2016 júniusában, amelyet a Bizottság is támogatott.

Az MMF szabályozási kereteire vonatkozó javaslatot a Bizottság 2013 szeptemberében fogadta el annak érdekében, hogy az új szabályoknak a pénzügyi rendszerre gyakorolt hatását fel lehessen mérni. Ezek a javaslatok figyelembe vették a Pénzügyi Stabilitási Tanács (Financial Stability Board - FSB) 2012 októberi ajánlásait. Az FSB javaslatainak elfogadása előrelépést jelentett abban a tekintetben, hogy az alapok ellenállóbbak lettek a beváltási rohamokkal szemben, feszült piaci körülmények között, miközben továbbra is biztos eszközei az európai vállalati finanszírozásnak.

A 2014-ben kezdődő uniós ciklus felénél az unió vezetői elérkezettnek látták az időt az unió helyzetének értékelésére és arra, hogy annak alapján felvázolják a fejlődés lehetséges irányait.

2017 márciusában „...az Európai Bizottság elnöke bemutatta az unió jövőjéröl szóló vitairatot, amely öt forgatókönyvet vázolt fel a brexit utáni lehetséges fejlődési 
irányokról. Az elsö a status quo megörzéséről szól: az integráció egyes területeken szorosabbá válna, de a tagállamok megöriznék szuverenitásuk legföbb elemeit. A második értelmében az unió fokozatosan leszükítené az integrációt az egységes belsö piac területére. A harmadik a többsebességes Európa gondolatát vázolja fel. A negyedik alapján a tagállamok mélyítenék az együttmüködést egyes kérdésekben, összességében azonban szükítenék a közös fellépés területeit. Az ötödik a föderális, az integrációt elmélyítő Európa irányába történő elmozdulás".

A lisszaboni szerződés megerősítése és több pontjának reformja mellett előterjesztették, hogy létre kell hozni az EU pénzügyminiszterének intézményét, amely kompetens lesz a közös EU-gazdaságpolitika és költségvetési politika megfogalmazására.

Szempontunkból, a bankrendszer lehetséges fejlődési irányainak szempontjából mérföldkövet jelentettek az eurózóna megerősítését célzó javaslatok. Ennek értelmében az euróövezet gazdaságait közelebb kell hozni egymáshoz, és ellenállóbbá kell tenni külső sokkokkal szemben. Megjelenik egy konvergencia- és felzárkózási stratégia, amelyet a tagállamok által finanszírozott, speciális euróövezeti költségvetés alapozna meg, amelyből átlátható módon lehetne forrásokhoz jutni.

A megvalósításhoz szükségesnek tartották olyan fiskális kapacitás létrehozását, amelynek része az Európai Stabilitási Mechanizmus (European Stability Mechanism - ESM), valamint további költségvetési források az eurózóna számára, amit a tagok finanszíroznak az EU-költségvetés részeként. További javaslat volt az Európai Monetáris Alap (European Monetary Fund) létrehozása, amely az ESM alapján fejlődne ki fokozatosan, és amelynek megfelelő hitelnyújtó és hitelfelvevő kapacitása lenne (megjegyzendő, hogy ezt a bemutatott jövőképet az Európai Parlament többsége megszavazta).

E folyamat részeként megfogalmazták az úgynevezett „konvergenciakódot”, öt év határidőt adva arra, hogy a konvergenciakritériumokat teljesítsék az adózás, munkaerőpiac, termelékenység és szociális kohézió terén.

Az előbbiekben felvázolt európai jövőképhez kapcsolódva röviden idézzük a fentiekkel kapcsolatos magyar elképzeléseket. Pár nappal az EU idézett parlamenti ülése után Varga Mihály (akkor nemzetgazdasági, jelenleg pedig pénzügyminiszter) a Bloombergnek az alábbiakat mondta:

7 1. Lásd még Haszon magazin, 2017. március.

2. EU-EP (2017): Az EU Parlament víziója, jövőképe Európa jövőjéről [Parliament sets out its vision for the future of Europe]. Plenary Session Press release - Future of Europe/European integration / Institutions, 16-02-2017). 
„Kétsebességes Európa - Fennáll a kockázata annak, hogy a kétsebességes Európában gondolkodók mostantól azt mondják: akik az eurózónában vannak, azok bent vannak a klubban, akik nincsenek, azok kint vannak a klubból.

Ez azzal a veszéllyel járhat, hogy a fejlett és kevésbé fejlett uniós tagállamok közötti szakadék nem fog jelentősen csökkenni a kétsebességes, brexit utáni Európa idöszakában. Ez pedig társadalmi feszültséget, nyugtalanságot gerjeszthet” - figyelmeztetett. Varga Mihály megismételte korábbi kijelentését, amely szerint „Magyarország jelenleg nem érdekelt az euró bevezetésében. Egy új világ nyílik meg. És ebben az új világban a gazdasági felzárkózásunkat érik kihívások." (portfolio.hu, 2017. február 27.)

A miniszter tehát megerősítette, hogy a kétsebességes Európa kialakulása reális veszély, elsősorban az eurózónán kívül lévők, maradók számára; ugyanakkor Magyarország nem szándékozik bevezetni az eurót, rövid távon nem célja az eurózóna tagjává válni.

A fejlődés és építkezés következő jelentős lépése az volt, amikor az Európai Bizottság 2016 novemberi, úgynevezett kockázatcsökkentő csomagjához (Risk Reduction Package) való hozzászólását követően, 2017 áprilisában az Európai Bankhatóság (European Banking Authority - EBA) elnöke tájékoztatta az Európai Parlamentet a banki és pénzügyi szektorra vonatkozó jogszabály-módosítási javaslatokról. Az Európai Bizottsággal egyetértésben javasolta a tőkekövetelményszabályozás (Capital Requirements Regulation - CRR), a tőkekövetelmény-direktíva (Capital Requirements Directive - CRD), a bankhelyreállítási és szanálási direktíva (Bank Recovery and Resolution Directive - BRRD) és az Egységes Szanálási Mechanizmus szabályozás (Single Resolution Mechanism Regulation SRMR) módosításának jóváhagyását.

Ezek a javaslatok hivatottak alkalmazni és az EU szabályozási rendszerébe beépíteni a nemzetközi sztenderdeknek azokat a kulcselemeit, amelyeket a Bázeli Bankfelügyeleti Bizottság (Basel Committee on Banking Supervision - BCBS) és a Pénzügyi Stabilitási Tanács (Financial Stability Board - FSB) dolgozott ki.

A javaslatok egyik követelménye az volt, hogy az EU szabályozási kereteit össze kell hangolni a nemzetközi sztenderdekkel. További feltétel volt a közös szabályok arányos alkalmazása, valamint az, hogy az uniformizált szabályok egyensúlyba kerüljenek a differenciált compliance-folyamatokkal úgy, hogy azok visszatükrözzék a banküzem komplexitását és kockázatait.

A cél tehát az arányosság növelése, az egységes szabálykönyv (Single Rulebook) egyszerűsített alkalmazása, valamint szükségtelen szabályozói terhek csökkentése volt, anélkül, hogy a prudenciális célok terén kompromisszumot kellett volna kötni. 
Az EBA hangsúlyosan javasolta válságkezelés esetén a bankhelyreállítási és szanálási direktíva (BRRD) alkalmazását, ami eltér az adófizetők pénzéből történő bankmentéstől (bail-out) és előnyben részesíti a veszteségek nemzetközi magánbefektetők útján történő kezelését (bail-in). Ez alól a szabály alól egy kivétel lehet: kivételes esetben megengedett közpénzből az elővigyázatos feltőkésítés.

Ennek az elvnek a támogatása érdekében javasolta az EBA egy európai eszközkezelő társaság (European Asset Management Company - AMC) felállítását vagy a nemzeti eszközkezelők forgatókönyvének elkészítését annak érdekében, hogy a piaci elégtelenségek, csődök, a gyors helyreállítás és az NPL-probléma kezelhető legyen. A Bizottság az EBA javaslatait szinte kivétel nélkül elfogadta.

A 2014-ben kezdődő ciklus második felében már egyértelműen az tapasztalható, hogy az unió döntés-előkészítő és döntéshozó intézményeiben a vizsgálódás előterébe az került, hogyan lehet és kell az addig kialakított és müködésbe lépett pénzpiaci intézményeket, a banki szabályozási és felügyeleti rendszert tovább fejleszteni, finomítani. Részletesen vizsgálták, hogy mi az, ami megvalósult és jól működik, hol van szükség módosításokra, illetve melyek még a hiányzó elemek. Ez utóbbiak esetében azt is felmérték, hogy bizonyos továbblépésekre (például a fiskális unió megvalósítására) megvan-e a politikai szándék, akarat és egyetértés. A fejlődés folyamán pedig megjelentek olyan új kihívások, amelyekre az EU-nak is reagálnia kellett. Ilyen kérdés volt például az egységes digitális piac kialakításának a követelménye.

A következőkben ezekről a folyamatokról adunk áttekintést.

\subsection{A ciklus második fele (2017-2019)}

2017. július 11-én az Európai Tanács döntést hozott a tőkepiaci unióról szóló cselekvési terv bizottsági felülvizsgálatáról.

A Tanács megerősítette elkötelezettségét a cselekvési terv iránt, amelynek célja a teljes körű tőkepiaci unió létrehozása 2019 végéig. A Tanács kiemelte, hogy a cselekvési terv végrehajtása jól halad, az intézkedések közel kétharmada már megvalósult. 2015. szeptemberi elindítása óta ugyanakkor több olyan kihívás jelentkezett, amelyek miatt szükségessé vált a cselekvési terv megerősítése. Ennek keretében szükséges a tőkepiacok erősítése, ezzel vonzóbbá téve az európai vállalatokat és infrastrukturális projekteket a befektetők - köztük a külföldi befektetők - számára; továbbá a forráshoz jutás javítása mindenekelőtt az európai kkv-k és induló vállalkozások esetében, különösen az innovatív iparágakban.

2017 decemberében az Európai Bizottság útitervet és konkrét intézkedéseket terjesztett elő azzal a szándékkal, hogy a Gazdasági és Monetáris Unió tovább erősödjön, és teljesüljenek azok a célok és kötelezettségvállalások, amelyeket a 
Juncker-terv és az öt elnök 2015. évi jelentése határozott meg. Az Európai Bizottság ismertette az Európai Gazdasági és Monetáris Unió elmélyítésére irányuló ütemtervet, és ezen belül a következő 18 hónap során végrehajtandó konkrét lépéseket. Az elsődleges cél, hogy 2025-ig egységesebbé, hatékonyabbá és demokratikusan elszámoltathatóbbá váljon az Európai Gazdasági és Monetáris Unió. Az Európai Bizottság egyben elfogadta az Európai Valutaalap (EMF) létrehozására vonatkozó javaslatot. A valutaalap az Európai Stabilitási Mechanizmus (ESM) már jól működő szerkezetére épül, és az EU jogrendjébe illeszkedik.

2018 elején már megállapítható volt, hogy a bankok helyzete javult, de továbbra is elsődleges feladat volt a jövedelmezőség növelése és a banki mérlegek megtisztítása.

A jövedelmezőség tekintetében az európai bankok lassan alkalmazkodtak a válság következményeihez, lassabban, mint például az amerikaiak. A tőkearányos megtérülés az euróövezet bankjaiban általában javult, egyes bankok esetében viszont még mindig nagyon alacsony volt. Ugyanakkor az EU általános gazdasági helyzete 2018-ban már jó lehetőségeket kínált ezeknek a feladatoknak a kezeléséhez. Az euróövezet jól működött, immár közel öt éve minden évben növekedett a gazdaság akár egyes országokat, akár szektorokat tekintve. A Bázel III-at befejezte a Bázeli Bizottság, ezáltal a pénzpiac stabilabbá vált - a bankok számára a szabályozási feltételeket illetően is -, bár még hátra volt a Bázel III alkalmazása, de ennek az EU-jogrendbe történő átültetése csak ezután valósulhat meg. 2018 volt az Európai Bankfelügyelet működésének negyedik éve, az építkezés időszaka egyértelmüen befejeződött. A felügyeleti keretrendszer stabilabbá és kiszámíthatóbbá vált.

A bankok stabilabb müködése szempontjából fontos volt, hogy az általuk alkalmazott belső kockázatszámítási modellek megfelelő kockázati súlyokat eredményezzenek. Ezen a ponton az Európai Központi Bank elindította a „Belső modellek célzott áttekintése” (Targeted Review of Internal Models - TRIM) nevü programot.

2018 végén, az addig eltelt időszak tapasztalatai alapján egyre markánsabban fogalmazódtak meg a Gazdasági és Monetáris Unió továbbfejlesztésének elmélyítésének követelményei. Be kellett látni, hogy az euró bevezetésének, az eurózóna létrehozásának voltak egyértelmü előnyei abban a tizenkilenc országban, amely az eurót alkalmazta. Létrejött tehát egy sok közös szabállyal rendelkező valutaövezet, ugyanakkor a gazdasági és költségvetési politikáért való felelősség továbbra is nemzeti hatáskörben maradt.

A Gazdasági és Monetáris Unió teljes felépítéséhez elengedhetetlenül szükséges a politikai és gazdasági konvergencia elmélyítése. Azt az EU-ban már régen felismerték: ha elégtelen a gazdasági konvergencia és hiányzik a közös költségvetési 
politika, akkor szorosabb gazdaságpolitikai koordinációra van szükség. Másképpen fogalmazva politikai integrációra és gazdasági konvergenciára van szükség, tovább kell erősíteni az eurózónát, és valódi gazdasági unióvá kell fejleszteni.

Ennek érdekében folytatni kell és végrehajtani a már korábban javasolt és elkezdett strukturális reformokat. Az Európai Bizottság azt javasolta, hogy a tagországok támogassák a reform-erőfeszítéseket az EU költségvetésén keresztül is úgy, hogy a reformokat a makrogazdasági kilátásokra gyakorolt hatásuk alapján kell kiválasztani. A reformok támogatásául szolgáló finanszírozást inkább egy minőségi értékelés alapján kell elosztani, nem pedig valamely országnak a „tortaszeletre” való jogosultsága alapján. Továbbá kell egy fegyelmezett visszacsatolási mechanizmus, hogy a források visszafizethetők legyenek, ha a reformok nem valósulnak meg.

A strukturális reformok mellett elengedhetetlen a stabil költségvetési politika kialakítása. A közös költségvetési szabályok képesek biztosítani, hogy a tagállamok ne vállaljanak túlzott mértékü adósságot, mivel az adósság alacsony szintje és a nagyobb pufferek nagyobb költségvetési teret biztosítanak az országok számára a gazdasági recessziók hatásainak mérséklésére.

Alapvető fontosságú eszközként irányozták elő egy központi fiskális kapacitás kialakítását, ami növelné az euróövezet ellenálló képességét súlyos, az egész övezetre kiterjedő recessziók esetén, és ezáltal támogatná a monetáris politikát.

A 2008-as válság felkészületlenül érte az Európai Uniót is, és a 2012-ben bekövetkező recesszió hozzájárult ahhoz a gyors döntéshez, hogy az uniós vezetők még abban az évben meg tudtak állapodni a bankunió létrehozásáról. Ennek első pillére az egységes szabálykönyv (Single Rulebook) volt, amit a bankok EU-szintü felügyeletének intézménye, az Egységes Felügyeleti Mechanizmus (SSM) követett. 2018-ban megérett a helyzet a továbblépéshez és a bankunió harmadik pillérének létrehozásához, ez az Egységes Szanálási Mechanizmus (SRM). Ez segíti a bankok szanálását olyan módon, hogy minimalizálja a szélesebb gazdaságra és a pénzügyi rendszerre gyakorolt hatást, egyben biztosítva, hogy már ne az adófizetők legyenek az elsődleges fizetők a bekövetkezett problémák esetén. A mechanizmus legfontosabb eleme az Egységes Szanálási Testület (SRB). Feladata, hogy gyorsan és határozottan reagáljon, amikor egy rendszerszintű vagy határokon átnyúló bank tevékenysége pénzügyi nehézségekbe ütközik. A bankunió nemzetek feletti állásfoglalási hatóságként ugyancsak létrehozta az Egységes Szanálási Tanácsot. 2018 júniusában az európai csúcstalálkozón közös megegyezéssel elfogadták az Európai Stabilitási Mechanizmus (ESM) müködését kiegészítő közös védőháló (Common Backstop) létrehozását, amely csak végső menedékként lesz elérhető, és igénybevétele esetén azt a bankszektor visszafizeti. A védőhálót az ESM hitelkeret formájában biztosítja úgy, hogy az SRF számára rendelkezésre álljon végső 
menedékként. A védőháló nem terheli a közfinanszírozást, mivel középtávon a bankszektor fedezi használatának költségeit az utólagosan (ex-post hozzájárulással) összegyüjtött, az adósemlegességet biztosító járulékokból.

A fentiekben láttuk, hogy a bankunió már meglévő „három pillérét”, az Egységes Felügyeleti Mechanizmust (SSM), az Egységes Szanálási Mechanizmust (SRM), az Európai Betétbiztosítási Rendszert (EDIS) folyamatosan erősítették, jobb működése érdekében kiegészítették.

2017 végén jelent meg az a javaslat a tőkepiaci unió továbbfejlesztése érdekében, hogy létre kell hozni egy pillért, a Páneurópai Eszközkezelő Vállalatot (European Asset Management Company - EAMC), amely képes lenne kezelni a nemteljesítő hitelek problémáját, az NPL-ráták csökkentését, ezáltal is segítve a beruházásokat és a növekedést az eurózónában. ${ }^{8}$

A bankunió teljes befejezése és azzal párhuzamosan a kockázatcsökkentés és a kockázatmegosztás terén való elörelépés volt hivatott segíteni a pénzügyi szektor határokon átnyúló integrációját, így egyik legfontosabb rövid távú feltétele volt az Európai Gazdasági és Monetáris Unió elmélyítésének.

2018. december 6-án ismertette a Bizottság a monetáris unió reformjáról szóló, úgynevezett „Szent Miklós-csomagot” (St. Nicholaus package). A javaslat tartalmazza az Európai Monetáris Alap (European Monetary Fund - EMF) létrehozását, ami az EU jogi keretrendszerének integráns része. Az EMF alapja az Európai Stabilitási Mechanizmus (European Stability Mechanism - ESM), feladata pedig a tagállamok és a bankok segítése pénzügyi nehézségek esetén.

Ezen felül a Bizottság javaslatot tett befektetésvédelmi rendszer (Investment Protection Scheme) létrehozására, aminek makrogazdasági stabilizáló hatása lenne aszimmetrikus sokkok idején. Ez azt is jelenti, hogy a Bizottság folytatni akarja az állami beruházások finanszírozását válság idején, ha egyébként ez a tagországok számára korlátozott lenne a költségvetési szabályok miatt.

A befektetésvédelmi program pozitív lépés az egyes EU-országokat érintő válsághatások enyhítésére. Eddig nem volt meg a lehetősége annak, hogy a válság hatásait beruházásokkal ellensúlyozzák. ${ }^{9}$

A fenti folyamathoz kapcsolódott, hogy az Európai Tanács 2017. december 12-én meghosszabbította az Európai Stratégiai Beruházási Alap (ESBA) időbeli hatályát

8 HeLen Louri (2017): A fourth pillar for Europe's banking union? The case for a pan-European asset management company in the Eurozone. European Politics and Policy, London School of Economics, 6 December.

9 Sven Giegold (2017): Reform of the Eurozone: Commission supports Macron instead of Merkel (6 December). 
2020. december 31-ig, ötszáz milliárd euró értékű további beruházást irányozva elö.

Ugyancsak 2018 decemberéhez kötődik az az egész eurózóna jövőjére vonatkozó bizottsági közlemény, amely szerint a decemberi Európai Tanács és az euróövezeti csúcstalálkozó döntései alapján a Bizottság intézkedéseket tesz az euró globális szerepének erősítése érdekében. ${ }^{10}$

Az euró ma már a második legfontosabb nemzetközi pénznem. Mintegy 340 millió európai polgár használja az euróbankjegyeket és érméket az euróövezet 19 tagállamában. A világ mintegy 60 országa használja, vagy összekapcsolja pénznemét az euróval. A nemzetközi fizetések széles körben elfogadott pénzneme, a külföldi központi bankok nemzetközi tartalékainak jelentős része és a nemzetközi piacokon történő adósságkibocsátás is euróban van.

Juncker elnök 2018. szeptemberi értékelő beszédében hangsúlyozta az euró stratégiai jelentőségét és annak szükségességét, hogy a közös valuta erős szerepet tölthessen be a nemzetközi színtéren: az Európai Gazdasági és Monetáris Unió megerősítésére irányuló döntésekkel és a bankunió teljes felépítésével elő kell mozdítani a tőkepiaci uniót, növelni kell az euró globális szerepét, amelynek tükröznie kell az euróövezet politikai, gazdasági és pénzügyi súlyát a globális térben.

\subsection{Digitális kihívások az Európai Unió pénzügyi rendszere számára}

A 2008-as nemzetközi pénzügyi válságot követő évtizedben, az EU utóbbi két ciklusában a negyedik ipari forradalom részeként megjelent a digitális fejlődés és a pénzügyi szektort is elérő digitális átalakulás korszaka. Ezek a változások olyan gyorsak és mélyrehatóak voltak, hogy azokra az EU-nak is reagálnia kellett. Az Európai Bizottság deklarálta, hogy az új digitális technológia döntő eleme lesz az EU jövőbeli versenyelőnyének.

A fintech (pénzügyi technológia) fogalmának nincs általánosan elfogadott definíciója a közgazdasági szakirodalomban. A Bázeli Bankfelügyeleti Bizottság (BCBS) a Pénzügyi Stabilitási Tanács (FSB) ideiglenes meghatározását használja a fintechre, amelynek értelmében jelentése „technológiavezérelt pénzügyi innováció, amely olyan új üzleti modelleket, alkalmazásokat, folyamatokat vagy termékeket eredményezhet, amelyek jelentős hatással lehetnek a pénzügyi piacokra és intézményekre, valamint a pénzügyi szolgáltatásokra”. Ez a tág meghatározás a

10 EC (2018): Commission presents ways to further strengthen the euro's global role. Brussels, 5 December. 
BCBS megítélése szerint pragmatikusan használható a fintech fejlődésének jelenlegi változékonysága mellett. ${ }^{11}$

Ez a megengedő és tág definíció természetesen komoly következményekkel jár. Mivel a meghatározás nem azonosítja egyértelmüen a fintechszolgáltatások tartalmát és körét, megnehezíti a felügyeleti ellenőrzések határait kijelölő jogszabályi keretek kialakítását, valamint a hagyományos bankok és a fintechvállalatok közötti verseny egyenlö feltételeinek biztosítását.

2015 májusában az Európai Unió egy nagyívű és átfogó tervnek, a digitális egységes piac stratégiájának (Single Digital Market Strategy) kidolgozásába kezdett, amelyet 2017-ben befejeztek. Ennek föbb elemei: a hozzáférés javítása az árukhoz, szolgáltatásokhoz és tartalmakhoz, a digitális hálózatok és szolgáltatások megfelelő jogi kereteinek kialakítása, valamint az adatalapú gazdaság előnyeinek kiaknázása. A versenyképesebb, innovatív pénzügyi piac stratégiai céljának érdekében 2018 márciusában az Európai Bizottság fintech cselekvési tervet tett közzé, amely a pénzügyi szolgáltatások terén megvalósított technológiavezérelt innovációkban (fintech) rejlö lehetőségek kiaknázására koncentrált.

„Az intézkedések célja, hogy Európa a pénzügyi technológiák globális központjává váljon, valamint, hogy az európai vállalkozások és befektetök a lehetö legnagyobb mértékben kihasználhassák azokat az elönyöket, amelyeket az egységes piac kinál e dinamikusan változó területen.” Első jelentős intézkedésként a Bizottság új szabályokat terjesztett elő a közösségi finanszírozást („crowdfunding”) biztosító platformok belső piaci növekedésének elősegítésére.

A közzétett cselekvési terv célja, hogy lehetővé tegye a pénzügyi szféra számára a gyorsan fejlődő új technológiák, például a blokkláncok, a mesterséges intelligencia és a felhőszolgáltatások alkalmazását. Az Európai Unió hatóságai, döntéshozói igyekeztek lépést tartani a pénzügyi szektort elérő, gyors digitális változásokkal. Ezt jól jelzi, hogy az uniós fintech cselekvési terv közzétételét követő napon, 2018 márciusában az Európai Bankhatóság (EBA) kiadta fintech munkatervét Szabályozói és felügyeleti fintech munkaterv kialakítása (Designing a Regulatory and Supervisory Roadmap for fintech) címmel.

Az EBA munkaterve fontos összefoglalása a hagyományos bankok és fintech startupok által nyújtott szolgáltatásokhoz szükséges és tervezett szabályozásnak. „A jelenlegi szabályozói megközelítések többsége a két szélsőség, a »megengedő és a "szabályozás és tiltás « között helyezkedik el. Ezek általában három összetevőn alapulnak: az innováció nyomon követése, a közérdeket érintö kockázatok érté-

11 Kerényi ÁdÁm - MÜller János (2019): Szép új digitális világ? - A pénzügyi technológia és az információ hatalma. Hitelintézeti Szemle, 18 (1), március. 
kelése (mikroprudenciális kérdések, pénzügyi stabilitás, fogyasztóvédelem és piaci integritás), valamint a fennálló szabályok szelektív alkalmazása.

Általánosságban ez a pragmatikus hozzáállás egy többszintű szabályozói struktúra köré szerveződik, a vállalatok, ügyfeleik, a pénzügyi szektor és a gazdaság egészének kockázatai szerint differenciált szabályozói követelményekkel. Elvben az a cél, hogy az »azonos kockázat, azonos szabályok « elvárása érvényesüljön.”

A pénzügyi szektort érintő digitális folyamatok felgyorsultak, a Pénzügyi Stabilitási Tanács és az Európai Központi Bank felhívta a figyelmet pénzügyi piaci struktúrát megbontó, veszélyeztető kockázatokra. Jelen írás keretei között ezeket a folyamatokat nem tudjuk bemutatni, mindössze három következményre irányítjuk rá a figyelmet. Egyrészt továbbra is megvan a fintech startupok támogatásának szándéka, gyakran azzal a céllal, hogy például a központi bankok vagy a felügyeletek jobban megismerjék a szabályozás részterületeinek szükségességét. Másrészt a gyors változások, határon átnyúló szolgáltatások miatt kialakult bizonyos kettősség: az EKB és más felügyeleti szervek hangsúlyozzák a nemzetközi együttmüködés, közös fellépés szükségességét, az azonos tevékenység, azonos szabályozás elvét, de e téren az előrelépés hiányában deklarálták, hogy a fintechszabályozásnak nemzeti hatáskörben kell maradnia. Harmadrészt elindult az önszabályozás igényének és az etikai iránymutatás szükségességének hangsúlyozása, az erre vonatkozó normák kidolgozása.

2019 áprilisában az Európai Bizottság kiadta a mesterséges intelligencia iránti bizalom kiépítésére szolgáló etikai iránymutatását. „Az AI etikai dimenziója nem luxus jellegü címke vagy kiegészítő elem. Csak a bizalom megléte esetén tudja társadalmunk teljes mértékben kihasználni a technológiákat. Az etikus AI mindenki számára win-win ajánlat, ami Európa versenyelönyévé válhat: az emberközpontú AI vezetöje lehet, amelyben az emberek bízhatnak" - deklarálta a digitális egységes piacért felelős vezető. Hét alapvető kritériumot határoztak meg a megbízható AI eléréséhez. Ezekből emelünk ki néhányat: 1) A megbízható AI-nek tiszteletben kell tartania minden alkalmazandó törvényt és elöírást. 2) Emberi képviselet és felügyelet: az AI-rendszereknek lehetővé kell tenniük az igazságos társadalmat az emberi képviseletek és az alapvető jogok támogatásával, és nem csökkenthetik, korlátozhatják az emberi autonómiát. 3) Adatvédelem és adatkezelés: a polgároknak teljes körü ellenőrzést kell gyakorolniuk saját adataik felett, míg az őket érintő adatok nem használhatók fel rájuk nézve káros vagy hátrányos megkülönböztetésre. ${ }^{12}$

12 EC (2019): Artificial intelligence: Commission takes forward its work on ethics guidelines). Brussels, 8 April. 
Az EU pénzügyi architektúrájáról és a digitális kihívásokról szólva meg kell említeni egy szabályozási fejleményt, amelynek az egész bankszektorra nézve hatása volt. Mint láttuk, a fintech startupvállalkozások megjelenését támogatás, fogyasztói bizalom fogadta, a bankok és a szabályozók piaci szerepüket marginálisnak, kockázatmentesnek tekintették. Ugyanakkor az elmúlt évtized második felében a fintech térhódítása forradalmian gyors volt, a hagyományos bankok jelezték, hogy a szabályozás nem biztosítja az egyenlő versenyfeltételeket és a PSD2 pénzforgalmi irányelvek módosítása jelentős adat- és piacvesztést eredményez számukra, ha maguk haladéktalanul nem indítanak nagy költségvonzatú digitális fejlesztéseket. A PSD2 lehetővé tette, hogy harmadik fél szolgáltatók (együttesen TPP) - hozzáférjenek API-n keresztül a bankok folyószámla-vezető rendszeréhez és az abban tárolt adatokhoz. Ez a fejlemény mérföldkő volt a hagyományos bankok és a fintech típusú szolgáltatók viszonyában.

\subsection{Fejlemények a ciklus végén, az európai parlamenti választások előtt}

A 2019-es uniós parlamenti választások és a mostani ciklus vége előtt az Európai Bizottság értékelte az európai pénzügyi felügyeleti rendszert. Az előrelépés feltételeként fogalmazta meg egy erősebb és integráltabb európai pénzügyi felügyeleti architektúra létrehozását. ${ }^{13}$

A Bizottság számára e dokumentum kiadását az tette lehetővé, hogy az Európai Parlament és a tagállamok márciusban megállapodtak az európai pénzpiaci felügyelet reformjának fontosabb elemeiben, amely szerint javítani fogják a felügyeletet az Európai Unióban azáltal, hogy megerősítik az európai felügyeleti hatóságok (ESA-k) szerepét és hatásköreit. A jól működő és működőképes tőkepiaci unió (CMU) biztosításához az EU-nak biztosítania kell, hogy a felügyelet lépést tartson a mélyülő integrációval. Ezen kívül az EU bankjaiban a pénzmosással kapcsolatos legutóbbi esetek megnövelték a pénzmosás elleni felügyeleti rendszer megerősítésének szükségességét.

Nézzük meg közelebbről, milyen területeket ölel fel ez a felhatalmazás. Az európai pénzügyi felügyeleti rendszer (European System of Financial Supervision - ESFS) 2010 novemberében jött létre a pénzügyi válságot követően, a Jacques de Larosière által vezetett szakértői csoport ajánlásai alapján. Ezt a rendszert úgy alakították ki, hogy megerősítse a pénzügyi felügyeletet és a bizalmat az EU új pénzügyi rendszere iránt. Az ESFS-nek két pillére van, az egyes ágazatokat és intézményeket felügyelő három európai felügyeleti ügynökség („mikroprudenciális pillér”) és az

13 EC (2019): Capital Markets Union: Creating a stronger and more integrated European financial supervisory architecture, including on anti-money laundering. Brussels, 1 April. 
Európai Rendszerkockázati Testület (ESRB), amely felügyeli a pénzügyi rendszert és koordinálja az uniós pénzügyi stabilitási politikákat („makroprudenciális pillér").

A három európai felügyeleti hatóság (ESA) tagjai: az Európai Bankfelügyeleti Hatóság (EBA), az Európai Biztosítás- és Foglalkoztatóinyugdíj-hatóság (EIOPA) és az Európai Értékpapír-piaci Hatóság (ESMA). Ezek hozzájárulnak az EU pénzügyi piacaira vonatkozó, egységes szabályok kidolgozásához, beleértve a pénzmosás elleni küzdelmet.

Az európai felügyeleti hatóságok feladata a pénzügyi szolgáltatások egységes piaca számára jobb müködési feltételek kialakítása; a pénzügyi piacok integritásának, átláthatóságának, hatékonyságának és rendezett müködésének biztosítása; a szabályozási arbitrázs megelőzése és az egyenlő versenyfeltételek előmozdítása; a pénzmosás elleni küzdelem hatékonyabbá tétele.

A fenti megállapodás kiemelte, hogy folytatni kell a bankunió és a tökepiaci unió teljes megvalósítását. Ennek értelmében az Európai Bankfelügyeleti Hatóság (EBA) átfogó felhatalmazást kapott, hogy az unió pénzügyi rendszerében a pénzmosás és a terrorizmus finanszírozása ellen hatékonyan felléphessen és ezt a követelményt beépítsék valamennyi érintett hatóság felügyeleti gyakorlatába.

A tőkepiaci unió részeként a Bizottság átfogó stratégiát dolgozott ki annak érdekében, hogy lehetővé tegye a digitális pénzügyi szolgáltatások integrált piacának kialakítását.

A fintechfolyamatok támogatásának első lépéseként az európai felügyeleti hatóságoknak figyelembe kell venniük a technológiai innovációval kapcsolatos valamennyi kérdést. Ez megköveteli, hogy az illetékes hatóságok között erősítsék a technológiai innováció tekintetében a közös uniós felügyeleti kultúrát. Kiemelten az európai felügyeleti hatóságokat bízták meg a nemzeti technológiai innovációs eszközök - például az innovációs csomópontok vagy a szabályozási tesztpályák, regulatory sandboxok - nemzeti felügyeletek általi koordinálásával.

Az elmúlt két ciklus fentiekben áttekintett fejlődését, az európai pénzügyi rendszer építményének alakulását, fontosabb építőelemeit az alábbi ábrán mutatjuk be. 


\section{1. táblázat}

\section{Az európai pénzügyi rendszer felépítése és fontosabb építőelemei}

\begin{tabular}{|c|c|c|c|c|}
\hline & & $\begin{array}{l}\text { Az eurózóna } \\
\text { költségvetése }\end{array}$ & $\begin{array}{c}\text { Európai } \\
\text { pénzügyminiszter } \\
\text { intézménye }\end{array}$ & \\
\hline & \multicolumn{2}{|c|}{ Integráció erősítése } & $\begin{array}{l}\text { Többsebességes } \\
\text { európai integráció }\end{array}$ & \\
\hline & \multicolumn{2}{|c|}{ Központi fiskális kapacitás } & $\begin{array}{c}\text { Speciális } \\
\text { konvergenciatámogatás }\end{array}$ & tás \\
\hline & \multicolumn{2}{|c|}{$\begin{array}{l}\text { Európai } \\
\text { eszközkezelő társaság }\end{array}$} & \multicolumn{2}{|c|}{$\begin{array}{l}\text { Befektetésvédelmi } \\
\text { rendszer }\end{array}$} \\
\hline & \multicolumn{2}{|c|}{ Európai Monetáris Alap } & \multicolumn{2}{|c|}{ Európai Valuta Alap } \\
\hline & \multicolumn{2}{|c|}{ Tökekövetelmény-direktíva } & \multicolumn{2}{|c|}{ Tőkekövetelmény-szabályozás } \\
\hline & \multicolumn{2}{|c|}{ Egységes szabálykönyv } & \multicolumn{2}{|c|}{$\begin{array}{l}\text { Bankhelyreállítási } \\
\text { és szanálási direktíva }\end{array}$} \\
\hline & \multicolumn{2}{|c|}{ Egységes Felügyeleti Mechanizmus } & \multicolumn{2}{|c|}{ Egységes Szanálási Mechanizmus } \\
\hline & \multicolumn{4}{|c|}{ Megvalósítás 2015-2025 között } \\
\hline & $\begin{array}{l}\text { Gazdasági és } \\
\text { Monetáris Unió }\end{array}$ & Bankunió & Tőkepiaci unió & Fiskális unió \\
\hline 2015 & \multicolumn{4}{|c|}{ Öt elnök jelentése, a GMU teljes megvalósítása: 2015-2025 } \\
\hline 2014 & \multicolumn{4}{|c|}{ Juncker-terv - reformprogram, az EMU felépítése } \\
\hline 2010 & \multicolumn{4}{|c|}{ Európai szemeszter - Gazdaságpolitikai koordináció } \\
\hline 1999 & \multicolumn{4}{|c|}{ Az euró bevezetése - Gazdasági és Monetáris Unió } \\
\hline 1993 & \multicolumn{4}{|c|}{$\begin{array}{l}\text { Maastrichti szerződés - Európai Unió, Európai Közösség } \\
\text { (Európai Gazdasági Közösség, Európai Szén- és Acél Közösség, Euratom) }\end{array}$} \\
\hline 1957 & \multicolumn{4}{|c|}{ Római szerződés - Európai Gazdasági Közösség } \\
\hline
\end{tabular}




\section{AZ EURÓPAI PÉNZÜGYI RENDSZER ÉPÍTMÉNYÉNEK JÖVÖKÉPE}

Mérföldkőhöz és szakaszhatárhoz érkezett tehát az Európai Unió pénzügyi rendszere, amikor a jövő alakításának tervezése megkívánja a számvetést. Az eddig megtett utat értékelte az Európai Parlament, az Európai Bizottság és az Európai Központi Bank. A legfontosabb kérdések áttekintése érdekében az Európai Parlament Gazdasági Bizottságának megállapításait vesszük alapul. ${ }^{14}$

Az unió pénzügyi építményének alapjával kapcsolatos kérdés: hogyan fejlődjön tovább az Európai Gazdasági és Monetáris Unió, milyen reformokra van szükség jobb, hatékonyabb működéséhez? Hogyan tud ellenállóbbá válni a lehetséges jövőbeni sokkokkal szemben?

Válaszra váró kérdés, hogy szükséges-e egy szorosabb, mélyebb fiskális és politikai unió. A 2008-as pénzügyi válság kitörését követően számos elemzés mutatott rá, hogy a monetáris unió építménye hiányos. Az idézett európai parlamenti elemzés arra a következtetésre jut, hogy a mélyebb fiskális és politikai integráció nem feltétele az EMU túlélésének, az előrelépéshez viszont nélkülözhetetlen, ami aláhúzza az egységes európai piac erősítésének, a bankunió és a tőkepiaci unió befejezésének a fontosságát. Az EMU elért fejlettségi szintje és a történelmi tapasztalatok azt mutatják, hogy a mélyebb politikai integráció az EU és EMU keretében hozzájárul az Európai Gazdasági Térség fenntarthatóságához.

Hogyan lenne erősíthető a fiskális és politikai unió? E kérdés eldöntéséhez választ kell adni arra, hogy a források és kompetenciák ilyen irányú centralizálása milyen előnyöket jelent. Alapvető, hogy az EU/EMU számára már elérhető kompetencia minden további centralizációjának a közös politikai célok megvalósítását kell segítenie, ellensúlyoznia kell a fellépő többletköltségeket, javítva az integráció hatékonyságát. Az integráció mélyítésének ezeken a területeken, valamint az EU mandátuma megfelelő bővítésének együtt kell járnia az uniós költségvetés növekedésével. Ez a fejlemény viszont fokozatosan nagyobb teret ad egy EU-szintü anticiklikus politika alkalmazásának, lehetővé válna olyan szövetségi pufferek igénybevétele, amelyek tompítanák az aszimmetrikus sokkokat.

Összefoglalva megállapítható, hogy az unió véleményformáló és döntés-előkészítő szakértőinek többsége az EMU teljes felépítéséhez szükségesnek tartja a fiskális és politikai integráció megvalósítását.

Az Európai Monetáris Unió jövője szempontjából az előttünk álló ciklusban kardinális kérdés az EMU bővítése, amely Litvánia 2015-ös csatlakozása után megállt. A 19 tagország mellett - ha eltekintünk az Egyesült Királyság, Dánia és Svédor-

14 EP (2019): The Economic and Monetary Union: Past, Present and Future. ECON Committee, European Parliament, January. 
szág sajátos helyzetétől - hat kívülálló ország marad. Közülük Bulgária, Románia és Horvátország bejelentette csatlakozási döntését, Csehország, Magyarország és Lengyelország viszont nem tartja időszerűnek a csatlakozást. Az Európai Bizottság álláspontja e kérdésben $A z$ Unió helyzete címü, 2017-ben kiadott dokumentum óta folyamatosan erösödik: eszerint kívánatos, hogy az EU-nak egyetlen közös valutája legyen, az euró. A 2020-at követő időszakra a Bizottság 2018-ban előirányzott egy speciális konvergenciatámogatást (Dedicated Convergence Facility) a csatlakozni szándékozók számára.Ez a támogatás a jóváhagyott, az eurót támogató reformprogram (Reform Support Programme) keretében érhető el. Az EU-ban az általános és erősödő politikai álláspont az, hogy a kívül maradók esetében tovább bonyolódik a többsebességes Európa, nem erősödik megfelelően a döntéshozatali rendszer, és egyre erősebb a bent lévők kritikája a kívülállók felzárkózási támogatásával szemben.

Az unió pénzügyi architektúrájával kapcsolatban - képletesen szólva - természetesen a „lakóknak” és „nyersanyagszállítóknak”, azaz a bankoknak is van jövőképe a 2019-2024 közötti ciklus időszakára vonatkozóan. Ezt a víziót dolgozta ki a 31 ország (EU-tagországok és társult tagok) bankszövetségeit összefogó Európai Bankföderáció. ${ }^{15}$ Összefoglaljuk ennek a jövőképnek a fontosabb megállapításait:

- Legyen egy integrált, egységes, erős pénzügyi szektor, amely finanszírozza a fenntartható gazdasági növekedést. Ennek érdekében az európai bankunió és tőkepiaci unió legyen különböző helyi, regionális és páneurópai szinteken elérhetö, teljesen integrált környezetben.

- A bankok és az ügyfelek kapcsolata legyen stabil bank-ügyfél kapcsolat és kevésbé egyedi, tranzakcióorientált kapcsolat.

- A bankszektor számára a verseny feltételei legyenek tisztességesek és egyenlő feltételeket biztosítók.

- A tőkepiaci unió megvalósítása szükséges, a tőkepiacoknak a bankok legyenek továbbra is kulcsszereplői, vagyis legyen nagyobb tőkepiac, de nem kisebb bankpiac.

- A pénzpiaci unió és a bankok biztonságos és eredményes működése érdekében a szabályozást felül kell vizsgálni és finomítani, elhárítva a szabályozás által előállt esetleges akadályokat. Felül kell vizsgálni - ahol szükséges - a jelenlegi prudenciális szabályozást a tőke- és likviditási követelmények esetében, amennyiben azok korlátozzák a bankok hitelezési képességét.

15 EBF (2019): Boosting Europe: EBF recommendations for the EU 2019-2024 legislative policy cycle and beyond. Manifesto, May.

EBF (2018): Financing the Europe of Tomorrow. A vision for policy makers, banks and markets in a changing world. 
- Létre kell hozni az digitális egységes piacot, amelynek megvalósításában a bankokat nélkülözhetetlen partnernek kell tekinteni.

- Erősíteni kell a befektetésvédelmet és a pénzügyi tudatosságot.

Az európai banki közösség jövőképének fenti elemeire nem szabad csak szólamokként tekinteni. Ezeknek a céloknak a megvalósulása érdekében a bankszektor támogatni fogja az unió döntéshozóinak a jövőképüknek megfelelő döntéseit, vagy ellenezni fogják a számukra negatív irányú fejleményeket. Röviden, aktív részesei lesznek az unió pénzügyi architektúrája alakításának.

\section{3. ÖSSZEFOGLALÁS, KÖVETKEZTETÉSEK}

A mérföldkőhöz és keresztúthoz érő Európai Unió helyzetéről, jövőjéről az elmúlt időszakban számos elemzés, vitaanyag jelent meg. Ezek a színskála minden árnyalatát képviselték, a helyzetet többnyire politikai síkon értékelve vagy fényes jövőt festettek fel, vagy megjósolták akár az unió szétesését. Kétségtelen, hogy a mögöttünk lévő évtized nem szükölködött nehéz és váratlan eseményekben, átéltünk egy globális pénzügyi válságot, recessziót, adósságválságot, majd megjelentek és élesedtek a geopolitikai feszültségek, megjelent és élesedett egy évtizedek óta nem tapasztalt kereskedelmi háború, és végül a brexitet övező bizonytalanság többéves folyamata. Ezzel a háttérrel ha nem is fogadható el, de érthető, hogy számos elemzést, prognózist inkább a negatív folyamatok érzelmi/politikai hatása vezérelt, mint a tényeken és szakmai alapokon nyugvó előretekintés. Ezzel összefüggésben külön is meg kell említeni a pénzügyi szektor és a pénzpiacok érzékeny reakcióját ezekre a folyamatokra.

Mindennek tudatában, ciklusváltáshoz érve, célul tűztük ki, hogy áttekintsük az Európai Unió pénzügyi építményének, architektúrájának fejlődését az elmúlt évtizedben, amely meghatározza a bankszektor müködésének jövőbeni feltételrendszerét is. Építményről szólva, a legszükségesebb mértékben bemutattuk azokat az alapokat, amelyek lehetővé tették a falak emelését és a belső terek kialakítását.

Három ikonikus évfordulót említettünk, az Európai Gazdasági Közösség létrehozását lehetővé tevő római szerződés 60 éves, az Európai Unióról szóló maastrichti szerződés 25 éves és az euró bevezetésének, illetve az eurózóna megalakításának húszéves évfordulóját. Ezek az évfordulók jelzik, hogy az alapok szilárdak, megbontásuk beláthatatlan következményekkel járna, tehát szilárd alapokon lehetett építkezni. Ezek az alapok hoztak bő hét évtizede tartó békét, jólétet és fejlődést Európának. Indokolt tehát, hogy az EU fejlődését és jövőképét történelmi perspektívába ágyazva vizsgáljuk, ezért elemeztük - többnyire időrendben - az elmúlt két ciklus időszakának fejleményeit. Az elmúlt évtizedben az Európai Unió működési mechanizmusát, pénzügyi intézményrendszerének építését számos tényező befolyásolta, segítette, vagy esetenként akadályozta. A gyökerek jogán, első 
helyen utaltunk magának az EGK-nak, az uniónak és az eurózóna alapításának dokumentumaira, mivel ezek meghatározták a müködés és a közösen elfogadott jövőbeli célok megvalósításának követelményeit. A „működtetéshez” szükség volt politikai döntésekre, bizonyos esetekben politikai szándékra és akaratra. Ezeket hol motiválták, hol visszafogták a két ciklusban bekövetkezett események. Az EGK, majd az Európai Unió megalapítását követően fundamentális változásokat az euró húsz évvel ezelőtti bevezetése, a Gazdasági és Monetáris Unió létrehozása vont maga után. Ettől az időponttól vált ketté az EU, jött létre az eurózóna a már tizenkilenc tagjával és a kívül maradók vagy ezután csatlakozók csoportjával. Mire az eurózóna megerősödött és bebizonyosodott, hogy müködőképes, bekövetkezett a 2008-as globális pénzügyi válság.

Ezek az az előzmények nagy hatással voltak az EU pénzügyi intézményi és szabályozói rendszerének fejlődésére. Egyértelművé vált, hogy egy ilyen mélységü pénzügyi sokk kezelésére az unió nincs felkészülve. Egyrészt bekövetkezett a pénzügyi és bankrendszerre vonatkozó túlszabályozás, a szabályokat alkalmazó intézményrendszer átalakítása, módosítása. Másrészt bebizonyosodott, hogy az EU képes a válság leküzdésére, és ez kikényszerítette a politikai belátást, hogy az uniót és elsősorban az eurózónát erősíteni kell. A válságkezelés miatt sok esetenként jogos - kritika érte az uniót, sokáig úgy tűnt, hogy kettős periféria alakul ki. Az első csoportba Görögország, Olaszország, Spanyolország, Portugália és Îrország, a másodikba pedig az eurózónán kívüli országok többsége került. A válság súlyos hatásait az elmúlt évtized közepére sikerült feldolgozni, az unió gazdasága növekedésnek indult. A görög válság kapcsán felmerült számos kritika miatt érdemes megjegyezni, hogy az országot nem azért érintette keményen a válság, mert az unió tagja volt, azt pedig utólag csak elképzelni lehet, mi történt volna, ha nem uniós tag Görögország.

A 2014-ben kezdődő ciklusban az unió pénzügy rendszerének fejlesztése több, egymással is kölcsönhatásban lévő síkon indult el. Elsősorban kidolgozták és elfogadták azokat a terveket (Juncker-terv, öt elnök jelentése, európai szemeszter), amelyek kijelölték a fejlődés kívánatos irányait és prioritásait. Ezek közös vonása volt az integráció erősítése, versenyképes, fenntartható gazdasági növekedés és egy robusztus, sokkokkal szemben ellenálló pénzügyi rendszer létrehozása. Az unió már meglévő alapzatára négy pillér felállítását tartották szükségesnek: Gazdasági és Monetáris Unió, tőkepiaci unió, fiskális unió és politikai unió.

Ebben a felállított keretrendszerben folyt a pénzügyi szabályozó rendszer és az előbbi négy pillér alá tartozó intézmények fejlesztése.

A szabályozórendszer terén kétirányú folyamat indult el. Egyrészt megkezdődött a válság utáni, válságkezelési célú szabályok felülvizsgálata, a Jobb szabályozás, jobb eredmények program végrehajtása. Másrészt felgyorsult a Gazdasági és Monetáris Unió működéséhez szükséges elemek kiépítése. 
Az Európai Pénzügyi Felügyeleti Rendszer müködését két intézmény támogatta, az Európai Rendszerkockázati Testület, valamint három európai felügyeleti hatóság, az Európai Bankfelügyeleti Hatóság, az Európai Biztosítás- és Foglalkoztatóinyugdíj-hatóság, valamint az Európai Értékpapír-piaci Felügyeleti Hatóság. Létrejött és müködött az egységes felügyeleti mechanizmus, az egységes szanálási mechanizmus, az egységes szanálási alap, és elindult az egységes betétbiztosítási rendszer kialakítása is. Az Európai Stabilitási Mechanizmus kiegészítéseképpen létrejött a közös védőháló, majd az Európai Monetáris Alap.

A mögöttünk lévő időszakban érte el a digitális fejlődés világa az EU-t, aminek a jelentőségét érzékelve, már 2015-ben kidolgozták a digitális egységes piac koncepcióját. A folyamat gyorsan, időnként erőszakosan nyomult a hagyományos bankok piacára. Kidolgozták az EU fintech akciótervét, de a fintechszabályozás a mai napig hézagos, nem képes megvalósítani az azonos szolgáltatások, azonos szabályozás elvét.

A 2019-es európai parlamenti választások előtt az Európai Bizottság - mintegy feladatot mutatva a megválasztásra kerülő uniós vezetőknek - értékelte a pénzügyi rendszer helyzetét. Megállapította, hogy jelentősen fejlődött a Monetáris Unió, de erösebb és egységesebb pénzügyi integrációra van szükség; ennek érdekében megállapodás jött létre a pénzpiaci felügyeleti rendszer reformjáról, a pénzpiaci felügyeletek hatásköreinek megerősítéséről. Kiemelt fontosságú a bankunió és a tőkepiaci unió építésének teljes befejezése a következő ciklusban.

E ponton lép be az EU pénzügyi és bankrendszerének jövőképe. A válságot közvetlenül követő években és az elmúlt két ciklusban nagy utat tett meg az EU pénzügyi rendszerének fejlődése. A továbblépés főbb elemei is egyértelműek: a monetáris, tőkepiaci és bankunió építésének befejezéséhez nagy horderejü politikai döntésekre van szükség. Ahol ugyanis nem sikerült elörelépni, az a fiskális unió, az integráltabb közös költségvetés kialakítása, a mélyebb költségvetési és gazdaságpolitikai koordináció, az uniós pénzügyminiszteri poszt létrehozása, az erősebb és ennek érdekében szigorúbb feltételekhez kötött konvergenciafolyamat. Hasonlóan kardinális kérdés, hogy milyen formában folytatható a pénzügyi architektúra szempontjából is kulcsfontosságú, kétsebességes Európa, hogyan és milyen áron bővíthető, tehető teljessé az eurózóna, mivel anélkül a monetáris unió sem lehet teljes. Sok szempontból bonyolult időszak előtt állunk. A tornyosuló problémák egy része, például a geopolitikai feszültségek, a kereskedelmi háború, a meghiúsult transzatlanti megállapodás az USA-val vagy akár a brexit bármilyen kimenetele nagy kihívásokat jelent, de egyúttal minden bizonnyal segíteni fogja a mag-Európa erősítésére irányuló politikai törekvéseket. 


\section{HIVATKOZÁSOK}

Bastasin, C. (2015): The Euro and the End of 2oth Century Politics. LUISS School of European Political Economy, October 2015.

BCBS (2017): Implications of fintech developments for banks and bank supervisors. BIS, 31 August, https://www.bis.org/bcbs/publ/d415.htm.

Cappiello, S. (2015): The interplay between the EBA and the Banking Union. Robert Schuman Centre for Advanced Studies, Working Paper, EUI RSCAS, 2015/77, 23 October.

DARVAS, Zs. - LeANDRo, A. (2015): The limitations of policy coordination in the euro area under the European Semester. Bruegel, November.

EBF (2016): Transatlantic Financial Regulatory Coherence Coalition: Financial Regulation in the TTIP. International Coalition for Transatlantic Cooperation in Financial Regulation. https:// www.ebf.eu/regulation-supervision/transatlantic-financial-regulatory-coherence-coalitionfinancial-regulation-in-the-ttip/, 7 Juin.

EBF (2018): Financing the Europe of Tomorrow. A vision for policy makers, banks and markets in a changing world. https://www.ebf.eu/financing-growth/vision-paper-financing-the-europe-oftomorrow/, 27 September.

EBF (2019): Boosting Europe: EBF recommendations for the EU 2019-2024 legislative policy cycle and beyond. Manifesto, https://www.ebf.eu/eu-agenda-2019-2024/boosting-europe-ebf-recommendations-for-the-eu-2019-2024-legislative-cycle-and-beyond-manifesto/, May.

EC (2015a): The Five President's Report: Completing Europe's Economic and Monetary Union. 22 June.

EC (2015b): Transatlantic Financial Regulatory Coherence Coalition: Financial Regulation in the TTIP. July.

EC (2015c): State of the Union 2015: https://ec.europa.eu/commission/publications/state-union2015-european-commission-president-jean-claude-juncker_en, 9 September.

EC (2015d): Capital Markets Union: Vital for Growth - Jonathan Hill; Eurofi Financial Forum, 10 September.EC (2015): Action plan on building a capital markets union | European Commission.. https://ec.europa.eu/info/publications/action-plan-building-capital-markets-union_en, 30 September.

EC (2016a): Investment Plan for Europe: European Fund for Strategic Investments to be extended following successful first year; European Commission, 1 Juin.

EC (2016b): Joint letter of Presidents Donald Tusk and. Jean-Claude Juncker on the upcoming G2o summit. Press release, https://www.consilium.europa.eu/hu/press/press-releases/2019/o6/26/ joint-letter-of-presidents-donald-tusk-and-jean-claude-juncker-on-the-upcoming-g2o-summit/, 26 Juin.

EC (2018a): New measures to boost key competences and digital skills, as well as the European dimension of education. Press release, https://ec.europa.eu/digital-single-market/en/news/newmeasures-boost-key-competences-and-digital-skills-well-european-dimension-education, 17 January.

EC (2018b): Speech by Commissioner Gabriel on building the European digital economy and society at the DLD conference. München, 22 January, https://ec.europa.eu/commission/presscorner/detail/en/SPEECH_18_390.

EC (2016c): Investment Plan for Europe: European Fund for Strategic Investments to be extended following successful first year. 1 Juin.

EC (2018d): Investment Plan results' - Investment Plan for Europe, July. 
EC (2018e): Commission presents ways to further strengthen the euro's global role. Brussels, 5 December.

EC (2019a): Capital Markets Union: Creating a stronger and more integrated European financial supervisory architecture, including on anti-money laundering. European Commission. Brussels, 1 April.

EC (2019b): Artificial intelligence: Commission takes forward its work on ethics guidelines). Brussels, 8 April.

EC (é. n.): What is the Investment Plan for Europe?, https://ec.europa.eu/info/investment-plan-europe/what-investment-plan-europe_en.https://ec.europa.eu > investment-plan-europe-junckerplan.

EP (2015): Opinion of European Think Tanks on the EMU. 18 December.

EP (2019a): The Economic and Monetary Union: Past, Present and Future. ECON Committee, European Parliament, January.

EP (2019b): Factsheet: The Juncker Plan's impact on jobs and growth, October.

EU-EP (2017): Parliament sets out its vision for the future of Europe]. Plenary Session Press release -Future of Europe/European integration/Institutions, 16-02-2017.

Giegold, S. (2017): Reform of the Eurozone: Commission supports Macron instead of Merkel. EP Diegrünen/EFA, 6 December.

Gnath, K. (2015): Why the euro area needs new convergence goals? Bertelsmann Stiftung, 4 December.

Gros, D. - Alcidi, C. (2015): Economic policy coordination in the euro area under the European Semester. Centre for European Policy Studies, No. 123, December.

HAAs, J. (ed., 2015): A fiscal union for Europe: Building block and not a magic bullet. Jacques Delors Institute - Berlin, Bertelsmann Stiftung, October 2015.

IIEA (2015): Comments on the five presidents' report, 'Completing Europe's Economic and Monetary Union'. iiea.com, 17 November.

IMF (2015): Building a Better Union: Intensivizing Structural Reforms in the Euro Area. IMF Working Paper, September.

Kerényi ÁdÁm - Müller János (2019): Szép új digitális világ? - A pénzügyi technológia és az információ hatalma. Hitelintézeti Szemle, 18 (1), március.

LARCH, M. - EC (2014): European Commission: The Stability and Growth Pact (SGP). In: DurLAuF, S. N. -Blume, L. E. (eds, 2014): The New Palgrave Dictionary of Economics, Chapter: The Stability and Growth Pact of the European Union. Palgrave Macmillan.

LOURI, H.(2017): A fourth pillar for Europe's banking union? The case for a pan-European asset management company in the Eurozone. European Politics and Policy, London School of Economics, 6 December.

QUED (2018): Conference on the Future of European Financial Infrastructure. 11 October.

Tusk, D. (2017): Speech by President Donald Tusk at the ceremony of the 6oth anniversary of the Treaties of Rome. https://www.consilium.europa.eu/en/press/press-releases/2017/03/25/tuskceremony-rome-speech/, 25 March.

Ungvári TAmás (2015): Csalódások kora. Budapest, Scolar Kiadó, 519. o.

ZuleEg, F. (2015): Can the eurozone's economic governance combine political accountability, legitimacy and effectiveness? European Policy Centre, 1 September.

ZuleEg, F. (2015): Unfinished Business: the governance of the Economic and Monetary Union). European Policy Center, 18 September. 